\author{
Т. С. Грузєва, Л. О. Литвинова, Н. В. Гречишкіна, О. М. Донік, Г. В. Іншакова \\ Національний медичний університет імені О. О. Богомольця, \\ Товариство фахівців соціальної медицини та громадського здоров'я Києва
}

\title{
ПИТАННЯ КОМУНІКАТИВНИХ КОМПЕТЕНЦІЙ У ПІДГОТОВЦІ ФАХІВЦІВ ГРОМАДСЬКОГО ЗДОРОВ’Я
}

\author{
T. S. Gruzeva, L. O. Litvinova, N. V. Grechishkina, O. M. Donik, G. V. Inshakova \\ O. Bohomolets National Medical University, \\ Kyiv Society for Social Medicine and Public Health

\section{THE ISSUE OF COMMUNICATIVE COMPETENCES IN THE PUBLIC HEALTH SPECIALISTS TRAINING}

\begin{abstract}
Мета роботи - з'ясувати роль і місце питань комунікації в навчальних планах та програмах підготовки фахівців громадського здоров’я у вищих навчальних закладах країн Європи і світу для обгрунтування відповідних освітніх нормативних документів в Україні.

Основна частина. Сфери застосування комунікаційних навичок у питаннях громадського здоров’я включають освіту, медичну журналістику, інформаційно-роз'яснювальну діяльність у засобах масової інформації, індустрію розваг, міжособистісне спілкування, комунікацію всередині організацій і між ними, поширення інформації про ризики, кризи і надзвичайні події, соціальну комунікацію і соціальний маркетинг.

Можливими формами комунікації є мультимедійні, інтерактивні, традиційні. Вибір форми комунікації повинен враховувати цільові аудиторії, культурні особливості тощо і включати міжособистісне спілкування, охоплення незначної чисельності населення, масові канали, включаючи телебачення, радіо, газети. Сучасними формами комунікації є використання блогів, обмін відеоматеріалами, мобільний телефонний зв’язок, онлайнові форуми. При цьому процесу комунікації повинна передувати адаптація інформації з різнобічних питань громадського здоров’я до особливостей конкретних груп споживачів.

Знання фахівцями громадського здоров’я комунікаційних технологій та володіння ними є запорукою ефективної протидії нездоровим формам поведінки і шкідливої для здоров’я продукції, зокрема алкоголю, тютюну. Вагомою умовою для успішної реалізації комунікацій у громадському здоров'ї є отримання зворотного зв'язку, що потребує вміння слухати, отримувати й аналізувати інформацію про сприйняття людьми меседжів для удосконалення комунікаційних процесів.

Дослідження планів підготовки бакалаврів та магістрів громадського здоров’я виявило, що вивченню питань комунікації відведено значний обсяг часу в Польщі, Болгарії, Угорщині, США.

Висновки. Володіння комунікативними компетенціями має важливе значення для забезпечення ефективної діяльності фахівців громадського здоров'я, що підтверджено концептуальними положеннями низки стратегічних та програмних документів міжнародного рівня.

Включення Асоціацією шкіл громадського здоров’я Європейського регіону комунікаційних компетенцій до основних компетенцій громадського здоров’я свідчить про необхідність забезпечення їх набуття в процесі навчання кадрів для громадського здоров'я.

Формування навчальних планів та програм підготовки бакалаврів і магістрів громадського здоров'я в Україні доцільно здійснювати з урахуванням національного контексту, рекомендацій міжнародних організацій та кращого зарубіжного досвіду.
\end{abstract}

Ключові слова: громадське здоров’я; комунікативні компетенції; навички; плани підготовки.

The aim of the work - to find out the role and the place of communication issues in the training programs of public health specialists at European and other world-class universities in order to substantiate the relevant educational regulations in Ukraine.

The main body. Communication skills in public health are used in such fields as education, medical journalism, outreach in the media, the show business, interpersonal communication, communication within organizations and between them, information dissemination on risks, crises and emergencies, social communication and social marketing.

Possible forms of communication are multimedia, interactive, traditional. The choice of communication form should take into account target audiences, cultural assumptions, etc., and should include interpersonal communication, the coverage of a small population base, mass-communication channels, considering television, radio, newspapers. Current forms of communication are the usage of blogs, video sharing, mobile phone service, online forums. Herewith, the communication process should be preceded by the adaptation of information about wide range of public health issues to the specifics of concrete consuming publics.

Public health specialist should know and master communication technologies as it is a guarantee of effective counteraction to unhealthy behavior pattern and unwholesome products, including alcohol and tobacco.

() Т. С. Грузєва, Л. О. Литвинова, Н. В. Гречишкіна та ін. 
The feedback receipt is critical to successful implementation of communication in public health and it requires the ability to listen, receive and analyze information about people's perceptions of messages for improving communication processes.

The study of Bachelors' and Masters' Public Health Training Programs revealed that a considerable amount of time was spent on studying communication in Poland, Bulgaria, Hungary, and in the USA.

Conclusions. Mastering of communicative competence is essential for the effective performance of public health specialists, as evidenced by the conceptual conditions of a number of world-class strategic documents and manifestos.

As the Association of Public Health Schools of the European Region listed communicative competences on the main competences of public health, it indicates the need to ensure the communicative competence acquisition in the process of public health staff training.

Formation of curricula and training programs for Bachelors and Masters in Public Health in Ukraine should be carried out taking into account the national context, international organizations recommendations and best foreign experience.

Key words: public health; communicative competences; skills; training programs.

Вступ. Стратегічні напрями реформування вітчизняної охорони здоров’я України передбачають формування сучасної системи громадського здоров’я, її інституційного та ресурсного потенціалу. Одним із важливих аспектів забезпечення громадського здоров’я ресурсами є підготовка достатньої за чисельністю та якістю когорти кадрів, раціональний розподіл кадрових ресурсів за рівнями, територіями, закладами, створення умов для постійного професійного розвитку.

Потужною доказовою базою для обгрунтування векторів розвитку громадського здоров'я $\epsilon$ низка стратегічних документів ЄРБ ВООЗ. У документі “Здоров’я-2020: основи європейської політики та стратегія для XXI століття” завдання з розбудови громадського здоров'я виділено в одну з пріоритетних сфер і представлено найбільш ефективні стратегії і підходи до формування національних служб [1]. Важливу роль у визначенні концептуальної основи траєкторії розвитку системи громадського здоров'я відіграє документ “Зміцнення потенціалу і служб громадського здоров’' в Європі: рамкова основа дій” [2].

Переконливі докази на користь пріоритетного розвитку служб громадського здоров'я в країнах наведено у виданні “Аргументи на користь інвестицій в громадське здоров’я”, в якому представлено економічні та медико-санітарні переваги використання підходу громадського здоров'я [3].

Ірунтуючись на положеннях вказаних міжнародних документів та враховуючи національний контекст, кожна країна формує чи вдосконалює нормативно-правову базу громадського здоров'я для ефективної протидії сучасним викликам.

В Україні активні процеси розбудови громадського здоров'я здійснюються відповідно до прийнятих стратегічних документів, які визначають головний вектор реформ. Згідно з Концепцією розвитку системи громадського здоров'я, в країні розпочато втілення ії̈ інституціональної структури, відкрито Національний центр громадського здоров'я та проводиться підготовча робота до відкриття регіональних центрів [4].

Одним із важливих завдань, окреслених Концепцією розвитку системи громадського здоров'я в Україні, $є$ формування людських ресурсів служби громадського здоров’я. На його виконання спеціальність “Громадське здоров’я” внесено до переліку спеціальностей, за якими здійснюється підготовка здобувачів вищої освіти, затверджено План заходів щодо реалізації Концепції, який передбачає створення освітніх стандартів, проектів навчальних планів, програм підготовки фахівців громадського здоров'я [5-6].

Національний медичний університет імені О. О. Богомольця один із перших серед ВМНЗ України розпочав системну роботу з обгрунтування та розробки проектів освітніх нормативних документів на основі аналізу зарубіжного досвіду і рекомендацій міжнародних організацій.

3 огляду на високі вимоги до якості підготовки фахівців громадського здоров'я, питання обгрунтування та розробки навчальних планів потребує комплексного міждисциплінарного підходу. В даному контексті серйозні вимоги висувають до забезпечення компетентнісної складової результатів навчання. Зважаючи на перелік функцій та завдань, які потрібно виконувати кадровим ресурсам у системі громадського здоров'я, засвоєння знань та оволодіння комунікаційними навичками для широкого застосування в повсякденній роботі $є$ необхідною умовою ефективності професійної діяльності.

Визначення ролі й місця комунікаційних технологій у системі підготовки кадрів громадського здоров’я потребувало аналізу сучасних стратегій, програм, рекомендацій міжнародних організацій в охороні здоров'я, вивчення існуючого світового та європейського досвіду формування відповідних кадрових ресурсів у країнах Європейського регіону ВООЗ та інших регіонів.

Мета роботи - 3'ясувати роль та місце питань комунікації в навчальних планах та програмах підготовки 
фахівців громадського здоров’я у вищих навчальних закладах країн Європи і світу для обгрунтування відповідних освітніх нормативних документів в Україні.

Основна частина. Джерельною базою слугували стратегічні та програмні документи ЄРБ ВОО3, освітні стандарти, навчальні плани і програми підготовки фахівців громадського здоров’я у вищих навчальних закладах країн Європи і світу, документи Асоціації шкіл громадського здоров’я Європейського регіону (ASPHER) щодо компетенцій громадського здоров'я. У роботі використано бібліосемантичний, аналітичний методи та системний підхід.

Вивчення та аналіз стратегічних і програмних документів ЄРБ ВООЗ засвідчили, що комунікативна компетентність $є$ важливою умовою забезпечення ефективної роботи фахівців охорони здоров'я. Однією з основних оперативних функцій громадського здоров'я є інформаційно-роз'яснювальна діяльність (адвокація), комунікація та соціальна мобілізація в інтересах здоров’я. Крім того, комунікативні навички $є$ необхідними для виконання інших дев'яти функцій громадського здоров'я.

Аналіз Європейського плану дій зі зміцнення потенціалу і послуг громадського здоров'я показав значення комунікації в роботі фахівців громадського здоров'я, форми, складові комунікації, завдання різних структур [7]. Реалізація фахівцями громадського здоров'я оперативної функції з інформаційно-роз'яснювальної діяльності (адвокації), комунікації та соціальної мобілізації в інтересах здоров'я передбачає підвищення медико-санітарної грамотності для поліпшення здоров'я окремих громадян, колективів, громад i населення країни в цілому. Досягнення цієї мети можливе при оволодінні фахівцями громадського здоров'я майстерністю та технікою інформування населення про існуючі ризики для здоров'я, методи їх мінімізації, впливу на окремих людей, їх групи і мотивації щодо здорової поведінки. Ефективна комунікація покликана підвищувати для населення доступність, ступінь сприйняття і можливості використання інформації з метою вибору необхідних послуг охорони здоров'я, а для осіб, які приймають рішення, сприяти реалізації заходів політики в охороні здоров'я.

Сфери застосування комунікаційних навичок у питаннях громадського здоров'я включають освіту, медичну журналістику, інформаційно- роз’яснювальну діяльність у засобах масової інформації, індустрію розваг, міжособистісне спілкування, комунікацію всередині організацій і між ними, поширення інформації про ризики, кризи і надзвичайні події, соціальну комунікацію і соціальний маркетинг.

Можливими формами комунікації є мультимедійні, інтерактивні, традиційні. Вибір форми комунікації повинен враховувати цільові аудиторії, культурні особливості тощо і включати міжособистісне спілкування, охоплення незначної чисельності населення, масові канали, включаючи телебачення, радіо, газети. Сучасними формами комунікації $\epsilon$ використання блогів, обмін відеоматеріалами, мобільний телефонний зв'язок, онлайнові форуми. При цьому процесу комунікації повинна передувати адаптація інформації з різнобічних питань громадського здоров'я до особливостей конкретних груп споживачів.

Знання фахівцями громадського здоров’я комунікаційних технологій та володіння ними є запорукою ефективної протидії нездоровим формам поведінки і шкідливої для здоров'я продукції, зокрема алкоголю, тютюну. Вагомою умовою для успішної реалізації комунікацій у громадському здоров'ї $є$ отримання зворотного зв'язку, що потребує вміння слухати, отримувати й аналізувати інформацію про сприйняття людьми меседжів з метою вдосконалення комунікаційних процесів.

Положення Європейського плану дій зі зміцнення потенціалу і послуг громадського здоров'я свідчать про те, що досягнення позитивних змін у здоров'ї та способі життя населення з використанням ефективної комунікації потребує підготовки нової генерації фахівців громадського здоров'я, які володіють сучасними комунікаційними технологіями, що необхідно врахувати у навчальних планах $\mathrm{i}$ програмах підготовки кадрів.

Вивчення документа ВООЗ “Інструмент самооцінки виконання основних оперативних функцій громадського здоров'я в Європейському регіоні ВООЗ” також підтвердило актуальність питань формування компетенцій з питань комунікацій у фахівців громадського здоров'я [8]. Сфери застосування комунікаційних технологій та навичок постійно розширюються. Підвищенню можливостей використання інформаційно-комунікативних технологій у громадському здоров'ї сприяє поява нових медіа і комунікаційних ін- 
струментів, у т. ч. електронних медичних карток, онлайн-інструментів навчання в системі безперервної медичної освіти, мобільних додатків для відстежування особистих показників здоров’я, приймання ліків тощо.

3 огляду на важливість підготовки персоналу для здійснення комунікацій у системі громадського здоров’я, ми провели аналіз документів Асоціації шкіл громадського здоров'я Європейського регіону щодо основних компетенцій фахівців громадського здоров’я. У керівництві “Від потенціалу до дії. Основні компетенції громадського здоров’я для важливих операцій громадського здоров’я”, яке видано ASPHER у 2016 р., викладено вимоги до фахівців громадського здоров’я щодо різних компетенцій, включаючи комунікаційні [9]. Необхідні компетенції охоплюють різні сфери діяльності фахівців громадського здоров’я і різні методи, включаючи епідеміологічні, демографічні, статистичні, кількісні та якісні методи досліджень, соціологічні, психологічні, антропологічні.

Необхідними інтелектуальними компетенціями професіонала громадського здоров'я з питань комунікації визначено знання основних теорій та концепцій, які лежать в основі комунікативних навичок, головних принципів комунікації. Практичними компетенціями є формування плану комунікації та його реалізації, володіння стратегічним та системним підходом до комунікації в громадському здоров’ї, організації ефективного спілкування, інтеграції комунікаційних стратегій, впровадження заходів з передачі інформації, використання ресурсів у процесі комунікації та соціальної мобілізації, можливості відстежувати та оцінювати комунікаційні кампанії.

Набуття фахівцями громадського здоров’ я вказаних компетенцій потребує включення їх до навчальних планів та програм підготовки кадрів.

Проведений аналіз нормативних освітніх документів з підготовки фахівців громадського здоров’я в зарубіжних країнах виявив, що комунікативні навички внесено до вимог освітніх стандартів багатьох країн світу, в т. ч. Польщі, Болгарії, Угорщини, США. Зокрема, в Польщі комунікаційні компетенції фахівців громадського здоров’я передбачено в стандартах освіти за першим (бакалавріат) та другим (магістратура) ступенями, які затвердило МОН Республіки Польща. В описі результатів навчання йдеться про необхідність визначення бакалавром громадського здоров’я перешкод на шляху впровадження медичної освіти серед населення на основі теорії соціальних змін і застосування відповідних методів навчання та навичок спілкування в дидактичному процесі.

Магістри громадського здоров’я повинні набути компетенцій планування, використання та оцінки процесу спілкування і переговорів.

Аналіз навчальних планів підготовки фахівців громадського здоров'я низки європейських та американських університетів виявив, що вивченню комунікації відведено значний обсяг часу. В навчальному плані підготовки бакалаврів громадського здоров’я Варшавського медичного університету виділено 2 кредити ESTC на набуття психосоціальних навичок з основ популяризації та навчання здорового способу життя, 2 - на керування проектами з популяризації, промоції здорового способу життя. У навчальному плані підготовки магістрів питання комунікації розглядають у процесі вивчення навчальних дисциплін “Досягнення промоції здорового способу життя”, на які виділено 4 кредити ESTC на першому році навчання, та “Засоби масової інформації”, на які відведено 1 кредит ESTC на другому році навчання.

У документі Ягеллонського університету “Детальна програма та план навчання за напрямом громадське здоров'я” відмічено, що, з точки зору роботодавців, для випускників громадського здоров’я необхідними компетенціями є відповідальність за власні дії та їх наслідки, вміння співпрацювати в команді, ефективне спілкування. Передбачено вивчення окремого модуля “Комунікація як професійний інструмент”, метою якого є отримання базових знань про процеси спілкування, набуття здатності використовувати теоретичні знання для пояснення процесів спілкування в контексті сприятливих факторів та перешкод, підготовка студента до правильного застосування отриманих знань на міжособистісному рівні, наприклад у контактах з іншими, у групі тощо. За результатами вивчення курсу, на який відведено 3 кредити ESTC, студент повинен володіти інформацією про процеси спілкування, вербальне та невербальне спілкування, коефіцієнти спілкування та його блокатори, а також про типи комунікаційних технологій, пояснювати етичні проблеми, пов'язані з методами впливу та стратегіями маніпулювання. Необхідними навичками є дотримання принципів вербального та невербального спілкування, налаштовування стилю спілкування на ситуаційні умови й цілі бесіди, демонстрування поваги до співрозмовника та приймання межі психо- 
логічного функціонування людини в процесі взаємодії, участі в обговоренні тем, роботи в команді.

У Вроцлавському медичному університеті вивчення комунікацій у процесі підготовки магістрів громадського здоров’я передбачає набуття компетенцій планувати комунікаційні процеси, оцінювати якість та ефективність спілкування на різних рівнях, визначати перешкоди на шляху впровадження медичної освіти серед населення на основі теорій соціальних змін і застосовувати відповідні методи та навички спілкування.

Дослідження навчальних програм та планів підготовки бакалаврів і магістрів громадського здоров’я інших країн Європи та світу показало включення до освітніх програм питань комунікації. Так, у навчальному плані підготовки бакалаврів громадського здоров'я Медичного університету Софії на вивчення навчальної дисципліни "Комунікативні навички та управління конфліктами” відведено 60 годин на четвертому році навчання.

У навчальному плані підготовки бакалаврів громадського здоров'я Університету Дебрецена в Угорщині на вивчення навчальної дисципліни “Навички комунікації” відведено 3 кредити ESTC. Отримання ступеня магістра громадського здоров'я передбачає оволодіння методами і практикою створення професійних та громадських зв'язків у курсі вивчення навчальної дисципліни “Промоція здорового способу життя”, на яку відведено 9 кредитів ESTC.

У США в Umas Lowel University комунікаційні знання та навички викладають у рамках наукових дисциплін “Технології в громадському здоров' 'ї” та

\section{Список літератури}

1. Health 2020 A European policy framework and strategy for the 21st century / WHO Regional Office for Europe Copenhagen, Denmark, 2013. - 190 p.

2. Strengthening Public Health Capacities and Services in Europe: A Framework for Action / WHO Regional Office for Europe. - Andorra la Vella, Andorra, 2011. - 53 p.

3. The case for investing in public health /WHO Regional Office for Europe. - Denmark, 2014. - 40 p.

4. Концепція розвитку системи громадського здоров'я в Україні [Електронний ресурс]. - 2016. - Режим доступу : http://moz.gov.ua/docfiles/Pro_20160309_0_dod.pdf.

5. Про внесення змін до Постанови Кабінету Міністрів України від 29 квітня 2015 р. № 266 : Постанова Кабінету Міністрів України від 01 лютого 2017 р. № 53 [Електронний ресурс]. - Режим доступу : http://www. kmu.gov.ua/control/uk/cardnpd?docid=248149695.
“Комунікативна техніка/популяризація здоров'я” на першому і четвертому роках навчання в бакалавріаті, й в програмі підготовки магістрів у рамках навчальної дисципліни “Комунікативні навички та технології в системі охорони здоров' я”. На кожну з вказаних дисциплін відведено по 3 кредити ESTC.

Отже, аналіз освітніх стандартів, навчальних планів та програм підготовки фахівців громадського здоров’я в зарубіжних країнах свідчить про включення до них як обов'язкового складника питань комунікації в громадському здоров ’і, що необхідно враховувати при формуванні освітнього контенту даного напряму в Україні.

Висновки. Володіння комунікативними компетенціями має важливе значення для забезпечення ефективної діяльності фахівців громадського здоров'я, що підтверджено концептуальними положеннями низки стратегічних та програмних документів міжнародного рівня.

Включення Асоціацією шкіл громадського здоров'я Європейського регіону комунікаційних компетенцій до основних компетенцій громадського здоров'я свідчить про необхідність забезпечення їх набуття в процесі навчання кадрів для громадського здоров'я.

Формування навчальних планів та програм підготовки бакалаврів і магістрів громадського здоров'я в Україні доцільно здійснювати з урахуванням національного контексту, рекомендацій міжнародних організацій та кращого зарубіжного досвіду.

6. Про затвердження плану заходів щодо реалізації Концепції розвитку системи громадського здоров'я : Розпорядження Кабінету Міністрів України від 18.08.2017 р. № 560 [Електронний ресурс]. - Режим доступу : http:// zakon3.rada.gov.ua/laws/show/560-2017-\%D1\%80.

7. European Action Plan for Strengthening Public Health Capacities and Services / WHO Regional Office for Europe. Copenhagen, Denmark, 2015. - 42 p.

8. Self-assessment tool for the evaluation of essential public health operations in the WHO European Region / WHO Regional Office for Europe Copenhagen, Denmark, 2015. - 113 p.

9. From Potential to Action. Public Health Core Competences. For Essential Public Health Operations. A manual. - 2016. - 75 p. 


\section{References}

1. (2013). Health 2020 A European policy framework and strategy for the 21st century. WHO Regional Office for Europe - Copenhagen. Denmark.

2. (2011). Strengthening Public Health Capacities and Services in Europe: A Framework for Action. WHO Regional Office for Europe. Andorra la Vella, Andorra.

3. (2014). The case for investing in public health. WHO Regional Office for Europe. Denmark.

4. (2016). Concept of development of public health system in Ukraine. 2016. [Electronic resource]. Retrieved from: http://moz.gov.ua/docfiles/Pro_20160309_0_dod.pdf

5. Resolution of the Cabinet of Ministers of Ukraine dated February 1, 2017 No. 53 “On Amendments to the Resolution of the Cabinet of Ministers of Ukraine dated April 29, 2015 No. 266”. - Retrieved from: http://www.kmu.gov.ua/control/ uk/cardnpd docid $=248149695$
6. Order of the Cabinet of Ministers of Ukraine "On Approval of the Plan of Measures to Implement the Concept of Development of the Public Health System" dated August 18, 2017, No. 560 - 2017. [Electronic resource]. - Retrieved from: / http://zakon3.rada.gov.ua/laws/show/560-2017$\% \mathrm{D} 1 \% 80$.

7. (2015). European action plan for strengthening public health capacities and services. WHO Regional Office for Europe. Copenhagen, Denmark.

8. (2015). Self-assessment tool for the evaluation of essential public health operations in the WHO European Region. WHO Regional Office for Europe - Copenhagen, Denmark.

9. (2016). From potential to action. public health core competences. For essential public health operations. A manual. 